\title{
Complete Genomic Characterization of Two Beet Soil-Borne Virus Isolates from Turkey: Implications of Comparative Analysis of Genome Sequences
}

\author{
Zohreh Moradi ${ }^{1}$, Hossein Maghdoori ${ }^{2}$, Ehsan Nazifi ${ }^{3}$, and Mohsen Mehrvar (iD) ${ }^{2 *}$ \\ ${ }^{1}$ Department of Plant Pathology, Faculty of Crop Sciences, Sari Agricultural Sciences and Natural Resources \\ University, P.O. Box 578, Sari, Iran \\ ${ }^{2}$ Department of Plant Pathology, Faculty of Agriculture, Ferdowsi University of Mashhad, P.O. Box 91779-1163, Mash- \\ had, Iran \\ ${ }^{3}$ Department of Biology, Faculty of Basic Sciences, University of Mazandaran, P.O. Box 47416-95447, Babolsar, Iran
}

(Received on December 11, 2020; Revised on January 26, 2021; Accepted on February 2, 2021)

Sugar beet (Beta vulgaris L.) is known as a key product for agriculture in several countries across the world. Beet soil-borne virus (BSBV) triggers substantial economic damages to sugar beet by reducing the quantity of the yield and quality of the beet sugars. We conducted the present study to report the complete genome sequences of two BSBV isolates in Turkey for the first time. The genome organization was identical to those previously established BSBV isolates. The tripartite genome of BSBV-TR1 and -TR3 comprised a 5,835-nucleotide (nt) RNA1, a 3,454-nt RNA2, and a 3,005-nt RNA3 segment. According to sequence identity analyses, Turkish isolates were most closely related to the BSBV isolate reported from Iran (97.8398.77\% nt identity). The BSBV isolates worldwide ( $n=$ 9) were phylogenetically classified into five (RNA-coat protein read through gene [CPRT], TGB1, and TGB2 segments), four (RNA-rep), or three (TGB3) lineages. In genetic analysis, the TGB3 revealed more genetic variability $(\mathrm{Pi}=\mathbf{0 . 0 3 4})$ compared with other regions. Population selection analysis revealed that most of the codons were generally under negative selection or

\footnotetext{
*Corresponding author.

Phone) +98-51-38805831, FAX) +98-51-38787430

E-mail)mehrvar@um.ac.ir

ORCID

Mohsen Mehrvar

https://orcid.org/0000-0003-1042-8660

(c) This is an Open Access article distributed under the terms of the Creative Commons Attribution Non-Commercial License (http:// creativecommons.org/licenses/by-nc/4.0) which permits unrestricted noncommercial use, distribution, and reproduction in any medium, provided the original work is properly cited.
}

Articles can be freely viewed online at www.ppjonline.org. neutral evolution in the BSBV isolates studied. However, positive selection was detected at codon 135 in the TGB1, which could be an adaptation in order to facilitate the movement and overcome the host plant resistance genes. We expect that the information on genome properties and genetic variability of BSBV, particularly in TGB3, TGB1, and CPRT genes, assist in developing effective control measures in order to prevent severe losses and make amendments in management strategies.

Keywords : beet soil-borne virus, complete genome, phylogenetic analysis, selection pressure, soil-borne virus

Handling Editor : Seung-Kook Choi

Sugar beet (Beta vulgaris L.) is one of the widely grown crops worldwide, which is grown commercially for sugar production. On top of excellent nutritional values, it provides over $25 \%$ of the world's sugar supply (Rush et al., 2006) and can be consumed in various forms. Sugar beet is one of the most important commercial crops in Turkey, grown over $307,067 \mathrm{ha}$, with an annual production of about 18.9 million tons (Food and Agriculture Organization of the United Nations, 2018). From viral sugar beet disease, the soil-borne viruses are the most dangerous threat to Turkish sugar beet industry, specifically beet necrotic yellow vein virus (BNYVV, the genus Benyvirus) the causal agent of rhizomania disease, and beet soil-borne virus (BSBV) which is present in most of the sugar beet cultivation areas. It could result into significant damages to sugar beet crop annually (Kutluk Yilmaz et al., 2004, 2016). BSBV is a member of the genus Pomovirus (the family Virgaviridae) 
(Adams et al., 2009), for the first time reported in England in 1982 (Henry et al., 1986). It could cause yield reduction up to $70 \%$ depending on the virus isolate and the sugar beet variety (Koenig et al., 2000; Prillwitz and Schlösser, 1992). Like other pomoviruses, BSBV genome is tripartite, consists of three positive-sense single-stranded RNA, packaged separately in three rod-shaped particles of trimodal length (Koenig and Loss, 1997; Koenig et al., 1996, 1997). RNA1, c. $5.8 \mathrm{~kb}$, encodes $145-\mathrm{kDa}$ (P145) and 204-kDa (P204) proteins which contain the motifs characteristic of proteins involved in viral RNA replication. These two proteins are $\mathrm{N}$-terminally overlapping in the same reading frame, the longer one being produced by readthrough of the shorter protein. RNA-2 is c. $3.5 \mathrm{~kb}$, encodes $19 \mathrm{kDa}$ coat protein (CP), and a putative $104 \mathrm{kDa}$ read-through domain that is thought to be involved in the transmission by Polymyxa betae (Torrance, 2008). RNA-3 is c. $3.0 \mathrm{~kb}$, encodes three movement proteins ( $\mathrm{P} 48, \mathrm{P} 13$, and $\mathrm{P} 22$ ), organized into a triple gene block (TGB) responsible for the virus cell-tocell movement (Crutzen et al., 2009). All three RNAs are flanked by untranslated regions. The $5^{\prime}$-untranslated region (UTR) of RNAs are capped and the 3'-end UTR forms a tRNA-like structure that is highly conserved with only seven nucleotide variations in the terminal 46 nucleotide (nt) (Koenig et al., 1998; Torrance et al., 2011). It is probably involved in viral functions including replication, as indicated by the varying valylatability of such extremities (Dreher, 2009; Mehrvar, 2009).

BSBV has a narrow host range in the nature restricted to Beta vulgaris and is mechanically transmissible to members of the Chenopodiaceae (Torrance, 2008). The virus is vectored by the biotrophic plasmodiophorid Polymyxa betae (Keskin, 1964; McGrann et al., 2009). To date, this virus has been reported from sugar beet-growing areas throughout the world from the USA, western and eastern Europe, Syria, Sweden, China, Japan, Iran, and Turkey (Borodynko et al., 2006; Farzadfar et al., 2007; Kutluk Yilmaz and Sokmen, 2010; Lesemann et al., 1989; Lindsten, 1989; Meunier et al., 2000, 2003; Mouhanna et al., 2002; Ratti et al., 2005; Verhoyen et al., 1987; Wang et al., 2008). Complete viral genome sequence data have provided new insights into the relationship among isolates from different areas, diversity and evolutionary history, and the possible origins of the virus (Moradi et al., 2016). The knowledge about genome sequence and structure in the study of sugar beet soil-borne viruses would help develop novel strategies for its control in agriculture. BSBV is known to be present in most of major sugar beet-growing areas of Turkey (Kutluk Yilmaz and Sokmen, 2010; Kutluk Yilmaz et al., 2004, 2016; Meunier et al., 2003). However, the complete genome sequences of BSBV Turkish isolates have not yet been determined. For the first time, the current study aimed to obtain the complete sequence of the BSBV in Turkey, their taxonomic status, and phylogenetic analysis in comparison to other isolates in GenBank.

\section{Materials and Methods}

Virus isolates. The soil samples were collected in 20092010 from sugar beet fields in Tokat province in Turkey and stored at $4{ }^{\circ} \mathrm{C}$. The sampling was performed in the symptomatic fields showing irregular patches of light green or yellow plants. Sugar beet (B. vulgaris cultivar Cadyx) was used as a bait plant. After one month, bait plants were harvested and their root sap was tested for the presence of the BSBV, BNYVV, beet virus Q (BVQ), and P. betae employing multiplex reverse transcription polymerase chain reaction (RT-PCR) developed by Meunier et al. (2003). All the samples were tested for the presence of BSBV utilizing RT-PCR with primers by Weiland et al. (2007). The plant's rootlets were washed and ground in $0.01 \mathrm{M}$ sodium phosphate buffer, $\mathrm{pH}$ 7.0. The extract was also mechanically inoculated in the upper side of Chenopodium quinoa leaves, a local lesion host of BSBV. BSBV was purified through three passages of single-lesion isolation on the leaves of $C$. quinoa.

Extraction of total RNA, PCR amplification, cloning, and sequencing. Total RNA was extracted from sugar beet roots using the SV Total RNA Extraction Kit (Promega, Madison, WI, USA) according to the manufacturer's protocol. The Expand Reverse Transcriptase kit (Roche, Mannheim, Germany), which includes a high-fidelity, thermostable polymerase, was used to generate complete cDNA fragments from each RNA using specific primers described by Mehrvar (2009). For this, $8.5 \mu$ l of diethyl pyrocarbonate (DEPC)-treated water was mixed with $1 \mu \mathrm{l}$ of antisense primer and $1 \mu \mathrm{l}$ of purified RNA, heated at $65^{\circ} \mathrm{C}$ for $10 \mathrm{~min}$ and chilled on ice. The mixture was added to 9.5 $\mu \mathrm{l}$ of mixed buffer (including $0.5 \mu \mathrm{l}$ of DEPC-treated water, $4 \mu \mathrm{l}$ of reverse transcriptase [RT] buffer, $2 \mu \mathrm{l}$ of DTT, 2 $\mu \mathrm{l}$ of dNTPs, and $1 \mu \mathrm{l}$ RT enzyme) and incubated at $43^{\circ} \mathrm{C}$ for $60 \mathrm{~min}$.

PCR was done using long expand PCR kit (Roche) as follows: $2.5 \mu \mathrm{l}$ of RT product was added to $47.5 \mu \mathrm{l}$ of mixed buffer (38.9 $\mu \mathrm{l}$ of DEPC-treated water, $4 \mu \mathrm{l}$ buffer 1 , $1.75 \mu \mathrm{dNTPs}, 0.8 \mu \mathrm{l}$ of each forward or reverse primers, and $0.75 \mu \mathrm{l}$ of long expand polymerase). The PCR thermal profile was $95^{\circ} \mathrm{C}$ for $2 \mathrm{~min}$ ( 1 cycle), followed by 10 cycles in $94^{\circ} \mathrm{C}$ for $10 \mathrm{~s}, 55^{\circ} \mathrm{C}$ for $10 \mathrm{~s}, 68^{\circ} \mathrm{C}$ for $2 \mathrm{~min}, 28$ cycles 
in $94^{\circ} \mathrm{C}$ for $15 \mathrm{~s}, 55^{\circ} \mathrm{C}$ for $30 \mathrm{~s}, 68^{\circ} \mathrm{C}$ for $2 \mathrm{~min}+20 \mathrm{~s}$ cycle elongation for each successive cycle and finally 1 cycle in $68^{\circ} \mathrm{C}$ for $7 \mathrm{~min}$. The long expand PCR products were separated by electrophoresis on $1 \%$ agarose gel containing $0.5 \mu \mathrm{g} / \mathrm{ml}$ DNA Green Viewer and visualized under UV irradiation. The PCR products of the expected size were extracted and purified from the agarose gel using the Qiaquick Gel Extraction Kit (Qiagen, Hilden, Germany). The purified products were ligated into the pGEM-T vector (Promega) according to the manufacturer's procedure. Ligation products were transferred into the Escherichia coli strain JM109. The positive clones were confirmed by colony-PCR using M13-forward and reverse primers and the virus-specific primers. Plasmid DNA from recombinant clones was purified using a Qiaquick Plasmid Miniprep Kit (Qiagen) and then was sequenced in both directions (Macrogen Inc., Seoul, Korea) by primer walking sequencing method. It is also worth noting that, the different sets of primers for sequencing of the full-length genome of BSBV were designed according to an Iranian BSBV sequence in the database (Nyshabour isolate) (Crutzen et al., 2009).

Sequence alignment and phylogenetic analysis. The complete sequences of $9 \mathrm{BSBV}$ isolates (two from this study and seven from GenBank) (Table 1) were analyzed to determine the phylogeny, genotype composition, and possible recombination events. The sequence comparisons were carried out using the BLAST algorithm (BLASTn and BLASTp) at the National Center for Biotechnology Information (NCBI). Open reading frames (ORFs) were identified using the NCBI ORF Finder program (http:// www.bioinformatics.org/sms2/orf_find.html). Gene translation and prediction of deduced proteins were performed using ExPASy (http://web.expasy.org/translate/). Motif searches were conducted in PROSITE (http://www.expasy. $\mathrm{ch} /$ ), and CDD (http://www.ncbi.nlm.nih.gov/Structure/ cdd/wrpsb.cgi) databases. RNA pseudoknot structure was predicted using the DotKnot program (Sperschneider and Datta, 2010). The nucleic acid sequences of Rep, coat protein read through (CPRT), TGB1, TGB2, and TGB3 genes were aligned by CLUSTALW using the IUB DNA weight matrix, whereas amino acid sequences were aligned by MUSCLE implemented in Geneious Prime version v. 2019.1.3 (Biomatters Ltd., Auckland, New Zealand). Comparison of nucleotide and amino acid sequence identities were carried out using the Geneious Prime 2019.1.3 (Biomatters Ltd.). Maximum-likelihood phylogenetic trees for each of the BSBV genes were constructed based on the best models in MEGAX (Kumar et al., 2018) with 1,000 bootstrap replicates. Genetic distances were estimated using the Kimura-2 parameter model in MEGAX and standard deviations were calculated by bootstrapping with 1,000 replicates. The nucleotide diversity $(\mathrm{Pi})$ value, nonsynonymous substitution rate $(\mathrm{dN})$, and synonymous substitution rate (dS) were calculated using the DnaSP6 (Rozas et al., 2017). Possible codons subjected to positive selection were identified utilizing three different codon-based maximumlikelihood algorithms, single likelihood ancestor counting, fixed effects likelihood (FEL), and mixed effects model of evolution (MEME) within the HYPHY software package as implemented in Datamonkey server (http://www. datamonkey.org) (Kosakovsky Pond and Frost, 2005) with

Table 1. Characteristics of beet soil-borne virus isolates used in this study

\begin{tabular}{|c|c|c|c|c|c|c|}
\hline \multirow{2}{*}{ Isolate } & \multicolumn{3}{|c|}{ Accession no. } & \multirow{2}{*}{ Host } & \multirow{2}{*}{ Country } & \multirow{2}{*}{ Reference } \\
\hline & RNA1 & RNA2 & RNA3 & & & \\
\hline TR1 & MN087411 & MN087412 & MN087413 & Beta vulgaris & Turkey & This study \\
\hline TR3 & MN087414 & MN087415 & MN087416 & Beta vulgaris & Turkey & This study \\
\hline IR-Neyshabur & FN386612 & FN386613 & FN386614 & Beta vulgaris & Iran & Crutzen et al. (2009) \\
\hline JKI 1825732 & MK731956 & MK731955 & MK731954 & Beta vulgaris & Germany & $\begin{array}{l}\text { Gaafar and Ziebell (unpub- } \\
\text { lished) }\end{array}$ \\
\hline PL & FJ971717 & FJ971718 & FJ971719 & Beta vulgaris & Poland & Borodynko et al. (2009) \\
\hline $\mathrm{XJ}$ & EF545139 & EF545141 & EF545143 & Beta vulgaris & China: Xinjiang & Wang et al. (2008) \\
\hline IM & EF545138 & EF545140 & EF545142 & Beta vulgaris & $\begin{array}{l}\text { China: Inner } \\
\text { Mongolia }\end{array}$ & Wang et al. (2008) \\
\hline Brazilian & MH106714 & MH106715 & MH106716 & Beta vulgaris & Brazil & Camelo-Garcia et al. (2019) \\
\hline Ahlum & Z97873 & U64512 & Z66493 & Beta vulgaris & Germany & $\begin{array}{l}\text { Koenig and Loss }(1997) \\
\text { Koenig et al. }(1996,1997)\end{array}$ \\
\hline
\end{tabular}

UTR, untranslated region; CPRT, coat protein read through; TGB, triple gene block. 


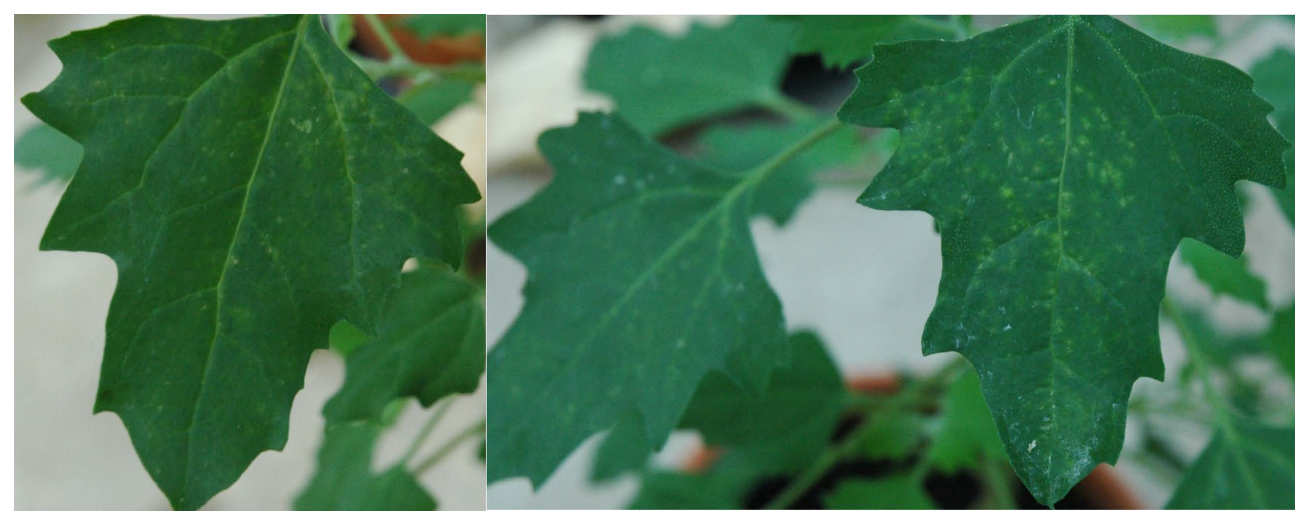

Fig. 1. Necrotic local lesion symptoms on Chenopodium quinoa leaves inoculated with sap from beet soil-borne virus (BSBV)-TR1 infected plants.

significance levels set at $P=0.1$. Recombination analysis was conducted using different algorithms implemented in the RDP4 v.4.16 (Martin et al., 2015).

\section{Results}

Virus detection by RT-PCR. Three out of four soil samples tested were positive for BSBV. The combination of BSBV with either BNYVV or BVQ was found in two samples. The characteristic symptoms of BSBV were also developed on inoculated leaves of $C$. quinoa. Necrotic local lesions were observed on inoculated leaves of $C$. quinoa seven days following the inoculation (Fig. 1). After retroinoculation to $C$. quinoa, RT-PCR tests of the inoculated plants showing local lesions confirmed the presence of BSBV. Five plants were inoculated, and all the plants demonstrated the symptoms of virus infection.

Genomic features of Turkish BSBV isolates. The complete genomes of isolates, TR1 (GenBank accession nos. MN087411, MN087412, and MN087413 for RNA1, RNA2, and RNA3, respectively) and TR3 (GenBank accession nos. MN087414, MN087415, and MN087416 for RNAs 1, 2, and 3, respectively) were determined. The genome organization and base composition of both isolates were similar to other BSBV isolates (Borodynko et al., 2009; Camelo-Garcia et al., 2019; Crutzen et al., 2009; Koenig and Loss, 1997; Koenig et al., 1996, 1997; Wang et al., 2008).

RNA1 of BSBV-TR1 and -TR3 consisted of 5,835 nt and contained the putative viral replicase domain with conserved motifs methyltransferase (MetT), helicase (Hel) and RNA-dependent RNA polymerase (RdRP). A large ORF starts at AUG (130-132) and is interrupted at position 3,940 by a stop codon UAA which terminates the first coding region (ORF1). It then continues in-frame for an additional $1,521 \mathrm{nt}$ until it reaches another stop codon UAA at nt 5,464 , which terminates the putative readthrough ORF2. An extra termination codon UAA was located at nt position 3,397-3,399 in TR3 isolate. On the other hand, the 5' and $3^{\prime}$ context of the first stop codon UAA in Turkish isolates (CAATAACGGTGTGGGTCG, stop codon underlined) is identical to those of BSBV RNA1, confers leakiness on stop codon UAA. The typical MetT, hel, and RdRP motifs (Koonin and Dolja, 1993) were recognized in the N- and C-terminal parts of the putative $145 \mathrm{kDa}$ protein and in the readthrough portion of $\sim 204 \mathrm{kDa}$ protein, respectively. In addition, blocks of highly conserved sequences were found in outside these motifs.

RNA2 of BSBV-TR1 and -TR3 consisted of 3,454 nt. The $19 \mathrm{kDa} \mathrm{CP}$ and a putative $104 \mathrm{kDa}$ read-through domain were identified in RNA2. Several pomovirus-conserved motifs were identified in the $\mathrm{CP}$ sequences of both isolates; for example, we observed the conserved residues $\mathrm{N}_{34} \mathrm{WRE}_{37}$ in the N-terminal, the $\mathrm{R}_{67} \mathrm{~F}_{68}$ and $\mathrm{F}_{154} \mathrm{E}_{155}$ motifs, which are typical for the coat proteins of rod-shaped plant viruses (Koonin and Dolja, 1993), in the central and carboxylic regions, and a conserved sequence $\mathrm{E}_{121} \mathrm{DSALN}$ $\mathrm{VAHQL}_{131}$ in the carboxylic end of CP.

The CP gene of BSBV RNA2, is terminated by stop codon UAG (position 875-877). It is followed in-frame by a 2,298 nt until it reaches a UAA stop codon at position 3176, which terminates the coat protein readthrough protein of BSBV. The context CAATCA flanking in the downstream of the leaky UAG codon conform to the optimal leaky UAG context (CAR \pm YYA) proposed by Skuzeski et al. (1991). The previously identified domains A, B, and $\mathrm{C}$, and the conserved regions $\mathrm{D}, \mathrm{E}$, and $\mathrm{F}$ (Koenig et al., 1997), were found in the readthrough protein of BSBV.

RNA3 of BSBV-TR1 and -TR3 consisted of 3,005 nt 
and contained a typical TGB. The three partially overlapping ORFs of TGB extend from 405-1,687, 1,6752,025 , and 1,889-2,461 nt, and have coding potential for proteins with molecular masses of 48,13 , and $22 \mathrm{kDa}$, respectively. In the central and C-terminal regions of 48 $\mathrm{kDa}$ protein, the highly conserved motifs $\mathrm{A}_{174} \mathrm{GSVT}$ GVPGSGKTTLLRK $_{191}, \mathrm{~N}_{199}$ SVVILANERHKIRFT $_{214}$, $\mathrm{V}_{236}$ LLIDEYT $_{243}, \mathrm{~V}_{262}$ VLFGDRAQ $_{270}, \mathrm{Y}_{288} \mathrm{SSVKSRRF}_{296}$, $\mathrm{I}_{351}$ ECSLVKDVQGNEYDSVSLFI $_{371}$, and $\mathrm{D}_{381}$ PELRSVAFTRHRK $_{394}$ were found which were corresponding to the typical helicase motifs I, IA, II, III, VI, V, and VI, respectively, described by Koonin and Dolja (1993).

The highly conserved motifs $M_{1}$ VRTNEIGARPNKY$\mathrm{WP}_{16}, \mathrm{~S}_{41} \mathrm{GDNIHKFSNGG}_{52}, \mathrm{R}_{69} \mathrm{AYNGSSSNN}_{78}, \mathrm{Y}_{95} \mathrm{AY}-$ VQYRKPQCTVTCRGEC ${ }_{113}$, were identified in the second TGB-encoded protein.

The 5'-UTR of both isolates RNA1s contained the starting sequence GUA (U)n, in agreement with the $5^{\prime}$ ends of most Pomovirus RNAs (Koenig and Loss, 1997; Koenig et al., 1996, 1997; Mehrvar, 2009). In addition, RNAs-2 and -3 begin with $\mathrm{GGU}(\mathrm{A})_{2}(\mathrm{U})_{4}$ and $\mathrm{GGUA}(\mathrm{U})_{9}$, respectively. A series of hairpin structures were detected in the $5^{\prime}$ ends of BSBV RNAs, as reported for BVQ (Koenig et al., 1998). The 3'-UTR of BSBV RNAs in both Turkish isolates contained the tRNA-like structures consisting of pseudoknot PKA, PKB, and PKC and stem-loops II-V, as reported by Koenig et al. (1998) for other BSBV and BVQ isolates. It has also been shown that these hairpins, in the $5^{\prime}$ and $3^{\prime}$ end of RNAs, are of great importance for replication, symptom production (Hellendoorn et al., 1997), and efficient translation and translational enhancement (Leathers et al., 1993; Simon and Miller, 2013).

Sequence comparison and genetic variability. The comparison of the Turkish BSBV genome sequences to the seven other isolates revealed $96.38-98.64 \%$ for RNA1, 95.02-98.37\% for RNA2, and $95.77-98.76 \%$ for RNA3 identity at the nucleotide level, and 97.18-98.93\% (RNA1), 95.38-98.38\% (RNA2), and 95.22-99.18\% (RNA3) identity at the amino acid level. TR1 and TR3 are more similar to the Iranian BSBV isolate (with the nt identity from 97.83 to $98.77 \%$ ). In a separate comparison, RNAs 1, 2, and 3 of BSBV-TR1 and -TR3 shared 99.90\%, 98.44\%, and $98.87 \%$ nucleotide sequence identities, respectively. The most conserved second TGB protein of TR1 shared 100\% amino acid sequence identity with that of TR3.

The average identities of the nine BSBV genomes were 97.38\% (96.38-99.89) for RNA1, 97.05\% (95.02-98.81) for RNA2, and 96.92\% (95.70-98.86\%) for RNA3 at the nucleotide level, and 98.14\% (97.18-99.83) (RNA1), 96.89\% (94.62-98.92) (RNA2), and 96.74\% (94.95-99.18) (RNA3) at the amino acid level, respectively (Table 2). The nucleotide diversity $(\mathrm{Pi})$ of all the three RNAs among the nine isolates was below $8 \%$ (Supplementary Fig. 1). RNAs

Table 2. Pairwise sequence identities of nine beet soil-borne virus isolates at both the nucleotide and amino acid levels, either at genome scale or at individual gene scale

\begin{tabular}{|c|c|c|c|c|}
\hline & Size (nt) & Size (aa) & $\begin{array}{l}\text { Percent nucleotide identity } \\
\text { (average) }(\%)\end{array}$ & $\begin{array}{l}\text { Percent amino acid identity } \\
\text { (average) }(\%)\end{array}$ \\
\hline \multicolumn{5}{|l|}{ Genomic segment } \\
\hline RNA1 & 5,835 & - & $96.38-99.89$ (97.38) & $97.18-99.83$ (98.14) \\
\hline RNA2 & 3,454 & - & $95.02-98.81(97.05)$ & $94.62-98.92(96.89)$ \\
\hline RNA3 & 3,005 & - & $95.7-98.86(96.92)$ & $94.95-99.18(96.74)$ \\
\hline \multicolumn{5}{|l|}{ Genomic region } \\
\hline 5'-UTR, RNA1 & 129 & - & $82.94-100(92.66)$ & - \\
\hline Rep, RNA1 & 5,337 & 1,778 & $96.12-99.88(97.40)$ & $97.18-99.83$ (98.14) \\
\hline 3'-UTR, RNA1 & 394 & - & $94.40-100(97.13)$ & - \\
\hline 5'-UTR, RNA2 & 382 & - & $94.50-99.47$ (97.66) & - \\
\hline $\mathrm{CP}$ & 495 & 164 & $96.76-99.79(98.23)$ & $98.78-100(99.59)$ \\
\hline CPRT, RNA2 & 2,796 & 931 & 94.49-98.71 (96.89) & 94.62-98.92 (96.89) \\
\hline 3'-UTR, RNA2 & 276 & - & $95.28-99.63$ (97.77) & - \\
\hline 5'-UTR, RNA3 & 404 & - & $92.59-99.00(95.93)$ & - \\
\hline TGB1, RNA3 & 1,281 & 427 & $95.16-99.14(96.97)$ & $96.25-99.06(97.65)$ \\
\hline TGB2, RNA3 & 384 & 116 & $96.83-99.13$ (97.79) & $97.79-100(97.67)$ \\
\hline TGB3, RNA3 & 573 & 190 & 94.93-99.30 (96.68) & $91.05-98.94$ (94.13) \\
\hline TGB, RNA3 & 2,057 & 733 & $95.52-99.02(97.00)$ & $94.95-99.18$ (96.74) \\
\hline 3'-UTR, RNA3 & 544 & - & $95.58-99.26(97.37)$ & - \\
\hline
\end{tabular}


1 and 2 of BSBV genomes were rather conserved. However, certain nonsynonymous mutations were found, most of which preserved the chemical properties of encoded amino acids.

The central parts of the MetT, Var, and RdRp coding regions on RNA1, the coding region of the CPRT domain on RNA2, the 5'- and 3'-UTRs of RNA3, and the $5^{\prime}$ end of TGB1 and $3^{\prime}$ end of TGB3 genes peaked at the variability of about $5 \%$. Among TGBs, only the $5^{\prime}$ part of the TGB1 depicted more variability (more than 6\%) (Supplementary Fig. 1). This finding is in line with that of other studies (Borodynko et al., 2009; Koenig et al., 2000; Wang et al., 2008). Consistent with previous studies (Borodynko et al., 2009; Wang et al., 2008), our results revealed that TGB3 $(\mathrm{Pi}=0.034)$ was a more variable gene region than TGB1 and TGB2. Sequence diversity in the 5'-UTRs and 3'-UTRs of RNA1 and RNA3 were relatively higher than those of RNA2 (Supplementary Table 1). The values of genetic dis-

A

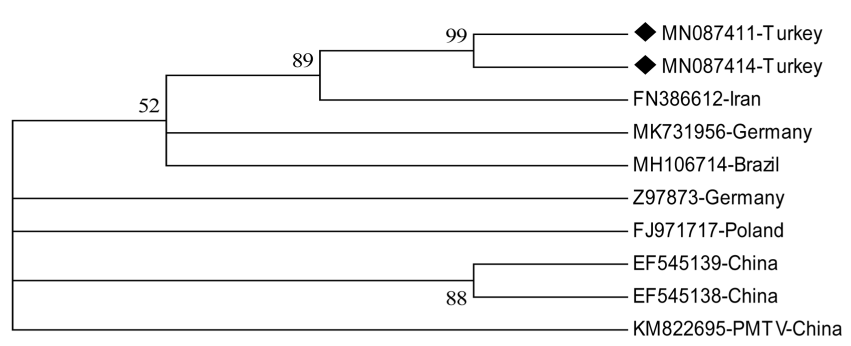

C

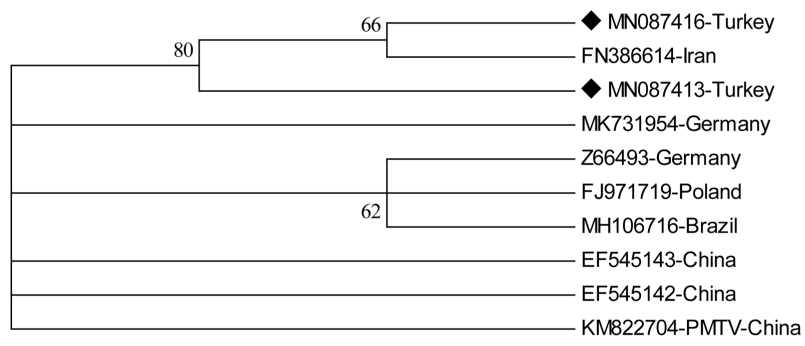

E

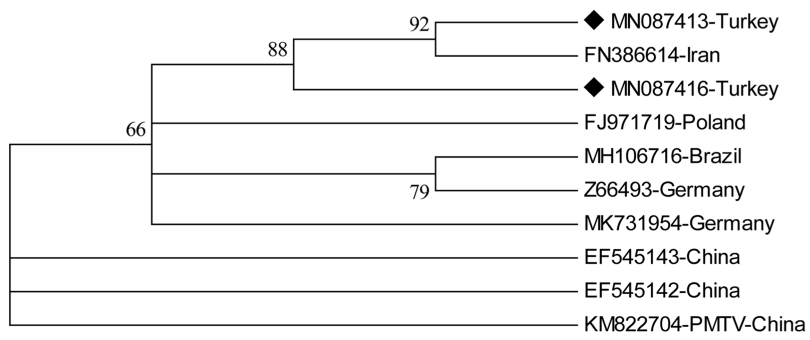

tances between the pairs of isolates for all RNA1, RNA2, and RNA3 coding regions ranged from 0.001 to 0.040 , 0.013 to 0.056 , and 0.010 to 0.047 , respectively. The overall mean value of genetic distance among coding regions of all the BSBV isolates was $0.027 \pm 0.001$ (RNA1), $0.031 \pm$ 0.002 (RNA2), and $0.031 \pm 0.002$ (RNA3), indicating low genetic diversity.

Pairwise sequence identities were analyzed at both the nucleotide and amino acid levels, at individual gene scale (Table 2), which confirmed the genetic variation results. The genetic variability of three genomic components together accounted for a total of 224 mutations identified by a single nucleotide polymorphism (SNP) analysis algorithm implemented in the Geneious Prime 2019.1.3 (Biomatters). Positions of SNPs in the genome were in replicase (113 SNPs), CPRT (65 SNPs), TGB1 (26 SNPs), TGB2 (5 SNPs), and TGB3 gene (15 SNPs). Altogether, these results indicated that the accumulation of mutations

B

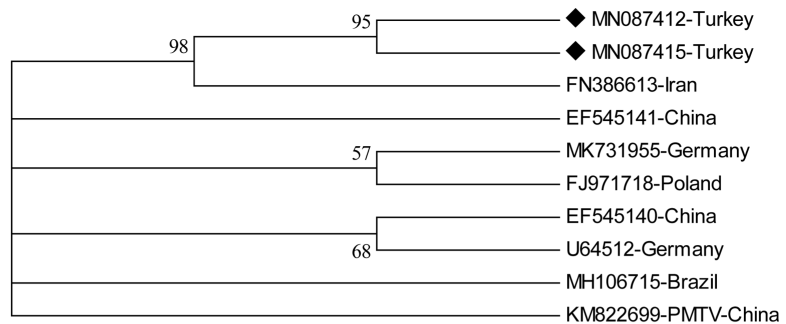

D

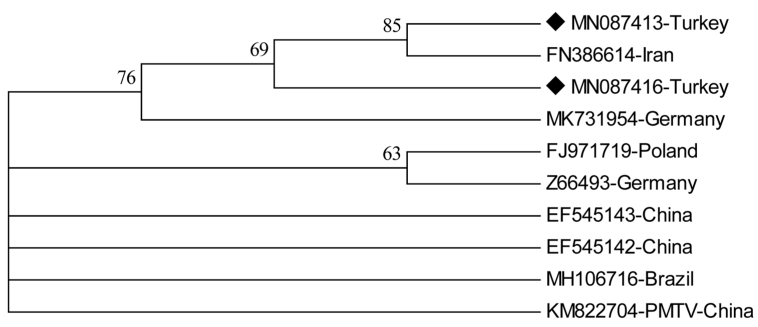

Fig. 2. Phylogenetic relationships among sequences of RNA-rep (A), RNA-CPRT (B), TGB1 (C), TGB2 (D), and TGB3 (E) genomic components of beet soil-borne virus (BSBV) inferred by MEGAX using the maximum likelihood method, with 1,000 bootstrap replications and with a $50 \%$ bootstrap threshold score. Isolates were indicated in the tree by accession number and geographical origin of collection. Turkish BSBV isolates generated from this study were marked. Potato mop-top virus was used as an outgroup. 
Table 3. Analysis of genetic diversity and selection pressure acting on different cistrons of beet soil-borne virus

\begin{tabular}{lccccccc}
\hline Genomic region & Pi & $d N$ & $d S$ & $d N / d S$ & $\begin{array}{c}\text { No. of negatively } \\
\text { selected sites }\end{array}$ & \multicolumn{2}{c}{ No. of positively selected sites } \\
\hline Rep & & & & & & FEL & MEME \\
CPRT & 0.02634 & 0.00901 & 0.10056 & 0.08959 & 159 & 0 & 9 \\
TGB1, RNA3 & 0.03093 & 0.01381 & 0.09076 & 0.15215 & 76 & 0 & 4 \\
TGB2, RNA3 & 0.03085 & 0.01075 & 0.10321 & 0.10415 & 31 & 1 & 1 \\
TGB3, RNA3 & 0.02239 & 0.00983 & 0.06632 & 0.14822 & 8 & 0 & 0 \\
\hline
\end{tabular}

FEL, fixed effects likelihood; MEME, mixed effects model of evolution.

was not evenly distributed among the five genomic regions of the BSBVs that were analyzed. It is also worth noting that no recombination signals were found in the genomic components of BSBV isolates.

Phylogenetic relationships among the nine aligned sequences of RNA-rep, RNA-CPRT, and RNA-TGB genomic components of the BSBV were inferred employing the maximum likelihood method from multiple sequence alignments (Fig. 2). The phylogenetic tree based on the complete RNA-rep sequences showed four lineages. Phylogenetic trees based on complete nucleotide sequences of the larger CPRT, RNA-TGB1, and TGB2 showed five lineages. The tree based on the complete RNA-TGB3 sequences represented three lineages. Phylogenetic analyses of BSBV isolates based on each of the genomes revealed that the TR1, TR3, and Iranian BSBV isolate belong to one cluster.

Selection pressure analysis. To assess the variation in selection pressure on each cistron, the $\mathrm{dN} / \mathrm{dS}$ ratios $(\omega)$ were also calculated separately for each gene (Table 3 ). The results revealed that the global selection pressure $(\mathrm{dN} / \mathrm{dS})$ for all the BSBV cistrons was less than 1, indicating negative or purifying selection pressure for amino acid conservation. As shown in Table 3, the $\mathrm{dN} / \mathrm{dS}$ ratio ranged from 0.02409 to 0.42213 , suggesting different constraints on sequence change depending on the virus gene. The strongest purifying selection belonged to the RdRP, supported by the smallest $\omega$ value (0.08959), while the weakest purifying selection was in the TGB3 protein, with the largest $\omega$ value (0.42213). Using HyPhy implemented in Datamonkey server, one amino acid at position 135 of TGB1 was detected by FEL and MEME method. No amino acid under positive selection was detected in other cistrons.

\section{Discussion}

Soil-borne viruses represent a group of particularly important pathogens, which cause severe yield losses in sugar beet crops. BSBV is commonly found in the fields where BVQ and BNYVV are also present (Meunier et al., 2003). Kutluk Yilmaz and Sokmen (2010) confirmed that the virus is widespread in sugar beet-growing areas of Turkey, including Tokat.

In this study, we determined the first complete nucleotide sequences of the three genomic components of two Turkish BSBV isolates. The putative proteins of Turkish BSBV isolates contained the conserved motifs with known functions for other pomoviruses.

Understanding the distribution of genetic diversity among individuals, populations, and gene pools are crucial for the efficient management of germplasm collections and breeding programs (Borodynko et al., 2009). According to prior studies, BSBV isolates are highly conserved regarding sequence variation and evolutionary divergence (Borodynko et al., 2009; Wang et al., 2008). Our sequence analysis confirmed that all BSBV isolates identified to date are closely related to each other and relatively conserved, particularly in the case of RNA1 ( $\mathrm{Pi}=0.02513)$.

The order of genetic variation of individual genes, from greatest to least, was as follows: TGB3, TGB1, CPRT, Rep, and TGB2 (Table 3). Despite the low mutation rate in BSBV genome sequences, genetic diversity and population genetic analysis at the genomic level could provide useful information regarding the evolutionary features of the BSBV genome.

The genome similarities between the Turkish isolates and those from other parts of the world were above $95 \%$. According to sequence identity analyses, Turkish isolates were most closely related to the BSBV isolates reported from Iran (97.83\% to $98.77 \%$ nt identity). The overall variability observed in BSBV worldwide suggested high genetic stability that could be explained by the ecological bottleneck imposed by vectors and host plants which reduce the genetic variation of the virus population (Borodynko et al., 2009). The replicase and CPRT cistrons accumulated the largest number of mutations whereas the TGB2 region harbored the lowest number of mutations. Our findings 
also revealed that the purifying selective pressure was not evenly distributed across the BSBV coding regions and distinct constraints affect different parts of the genomes. Most of the codons were under negative selection or neutral evolution; however, positive selection was detected at codon 135 in the TGB1 genomic region, which reflects the molecular adaptation. BSBV RNA-TGB encodes a movement module, the TGB, and this codon may be critical in the function of TGB1 in cell-to-cell and possibly long-distance movement. On the other hand, molecular adaptation owing to positive selection has been described in several plant viruses; for instance, the amino acid change of $\mathrm{C}$ to $\mathrm{Y}$ at codon 118 of tomato spotted wilt tospovirus (TSWV) $\mathrm{NSm}$ movement protein resulted in breaking the resistance conferred by the tomato Sw-5 gene (López et al., 2011). Therefore, the positive selection at codon 135 could be an adaptation to facilitate the movement and to overcome host plant resistance gene. Nevertheless, the significance of positively selected codon in the host virus-vector interactions need to be further investigated. The phylogenetic analysis showed a lack of clustering by geographical origin, which emphasizes the importance of the exchange and use of virus-free plant material in preventing the dissemination of this virus. Sugar beet, the only identified natural host of BSBV, is frequently a symptomless host, and the actual effects of BSBV on sugar beet are unknown although it has been shown that it is infectious in C. quinoa using fulllength infectious clone from Iran (Crutzen et al., 2009). The two newly characterized BSBV isolates from Turkey confirmed this observation. BSBV can persist in soil within the long-lived resting spores of the plasmodiophorid vectors which allow the virus to infect sugar beet for over ten years after the last crop. Accordingly, it is impossible to get rid of it even with long rotation (Mehrvar, 2009) and thus, controlling it is dependent on the development of resistant cultivars (Tamada and Kondo, 2013). On the other hand, the introduction of viruses to new areas and continuous use of resistant cultivars may lead to the emergence of new variants and resistance-breaking virus strains via amino acid changes in pathogenicity-related viral genomes. Moreover, BSBV was found in combination with either BNYVV and/ or BVQ, suggesting the potential for the evolution of new strains and resistance-breaking variants through recombination. The sequence characteristics and the observed genetic diversity reported in this study would be useful in the breeding of resistant varieties and developing effective control strategies. However, to understand the global molecular epidemiology and geodynamics of BSBV, there is a need for a larger number of complete genome sequences of $\mathrm{BSBV}$ isolates from several countries.

\section{Acknowledgments}

The authors thank Professor Nazli Dide Kutluk Yilmaz at the University of Ondokuz Mayis for collecting samples.

\section{Conflicts of Interest}

No potential conflict of interest relevant to this article was reported.

\section{Electronic Supplementary Material}

Supplementary materials are available at The Plant Pathology Journal website (http://www.ppjonline.org/).

\section{References}

Adams, M. J., Antoniw, J. F. and Kreuze, J. 2009. Virgaviridae: a new family of rod-shaped plant viruses. Arch. Virol. 154:1967-1972.

Borodynko, N., Hasiów, B. and Pospieszny, H. 2006. First report of beet soilborne virus in Poland. Plant Dis. 90:112.

Borodynko, N., Hasiów-Jaroszewska, B., Rymelska, N. and Pospieszny, H. 2009. Full length genome sequence of Polish isolate of beet soil-borne virus confirms low level of genetic diversity. Acta Biochim. Pol. 56:729-731.

Camelo-García, V. M., Rezende, J. A. M. and Nagata, T. 2019. First report of beet soil-borne virus on red table beet in Brazil. Plant Dis. 103:2146.

Crutzen, F., Mehrvar, M., Gilmer, D. and Bragard, C. 2009. A full-length infectious clone of beet soil-borne virus indicates the dispensability of the RNA-2 for virus survival in planta and symptom expression on Chenopodium quinoa leaves. $J$. Gen. Virol. 90:3051-3056.

Dreher, T. W. 2009. Role of tRNA-like structures in controlling plant virus replication. Virus Res. 139:217-229.

Farzadfar, S., Pourrahim, R., Golnaraghi, A. R. and Ahoonmanesh, A. 2007. Surveys of beet necrotic yellow vein virus, beet soil borne virus, beet virus Q and Polymyxa betae in sugar beet fields in Iran. J. Plant Pathol. 89:277-281.

Food and Agriculture Organization of the United Nations. 2018. FAOSTAT. URL http://www.fao.org/faostat/en/\#home [19 February 2021].

Hellendoorn, K., Verlaan, P. W. G. and Pleij, C. W. A. 1997. A functional role for the conserved protonatable hairpins in the 5 ' untranslated region of turnip yellow mosaic virus RNA. $J$. Virol. 71:8774-8779.

Henry, C. M., Jones, R. A. C. and Coutts, R. H. A. 1986. Occurrence of a soil-borne virus of sugar beet in England. Plant Pathol. 35:585-591.

Keskin, B. 1964. Polymyxa betae n.sp., a parasite in the roots of Beta Vulgaris Tournefort, particularly during the early growth of the sugar beet. Arch. Mikrobiol. 49:348-374 (in German). 
Koenig, R., Beier, C., Commandeur, U., Lüth, U., Kaufmann, A. and Lüddecke, P. 1996. Beet soil-borne virus RNA 3: a further example of the heterogeneity of the gene content of furovirus genomes and of triple gene block-carrying RNAs. Virology 216:202-207.

Koenig, R., Commandeur, U., Loss, S., Beier, C., Kaufmann, A. and Lesemann, D. E. 1997. Beet soil-borne virus RNA 2: similarities and dissimilarities to the coat protein gene-carrying RNAs of other furoviruses. J. Gen. Virol. 78:469-477.

Koenig, R. and Loss, S. 1997. Beet soil-borne virus RNA 1: genetic analysis enabled by a starting sequence generated with primers to highly conserved helicase-encoding domains. $J$. Gen. Virol. 78:3161-3165.

Koenig, R., Pleij, C. W., Beier, C. and Commandeur, U. 1998. Genome properties of beet virus $\mathrm{Q}$, a new furo-like virus from sugarbeet, determined from unpurified virus. J. Gen. Virol. 79:2027-2036.

Koenig, R., Pleij, C. W. and Büttner, G. 2000. Structure and variability of the 3' end of RNA 3 of beet soil-borne pomovirus: a virus with uncertain pathogenic effects. Arch. Virol. 145:11731181.

Koonin, E. V. and Dolja, V. V. 1993. Evolution and taxonomy of positive-strand RNA viruses: implications of comparative analysis of amino acid sequences. Crit. Rev. Biochem. Mol. Biol. 28:375-430.

Kosakovsky Pond, S. L. and Frost, S. D. 2005. Not so different after all: a comparison of methods for detecting amino acid sites under selection. Mol. Biol. Evol. 22:1208-1222.

Kutluk Yilmaz, N. D. and Sokmen, M. A. 2010. Occurrence of soilborne sugar beet viruses transmitted by Polymyxa betae northern and central Turkey. J. Plant Pathol. 92:507-510.

Kutluk Yilmaz, N. D., Sokmen, M. A., Kaya, R., Sevik, M. A., Tunali, B. and Demirtaş, S. 2016. The widespread occurrences of beet soil borne virus and RNA-5 containing beet necrotic yellow vein virus isolates in sugar beet production areas in Turkey. Eur. J. Plant Pathol. 144:443-455.

Kutluk Yilmaz, N. D., Yanar, Y., Günal, H. and Erkan, S. 2004. Effects of soil properties on disease occurrence of beet necrotic yellow vein virus and beet soilborne virus on sugar beet in Tokat, Turkey. Plant Pathol. J. 3:56-60.

Kumar, S., Stecher, G., Li, M., Knyaz, C. and Tamura, K. 2018. MEGA X: molecular evolutionary genetics analysis across computing platforms. Mol. Biol. Evol. 35:1547-1549.

Leathers, V., Tanguay, R., Kobayashi, M. and Gallie, D. R. 1993. A phylogenetically conserved sequence within viral 3' untranslated RNA pseudoknots regulates translation. Mol. Cell. Biol. 13:5331-5347.

Lesemann, D.-E., Koenig, R., Lindsten, K. and Henry, C. 1989. Serotypes of beet soil-borne furovirus from FRG and Sweden. OEPP/EPPO Bull. 19:539-540.

Lindsten, K. 1989. Investigations concerning soil-borne viruses in sugarbeet in Sweden. OEPP/EPPO Bull. 19:531-537.

López, C., Aramburu, J., Galipienso, L., Soler, S., Nuez, F. and Rubio, L. 2011. Evolutionary analysis of tomato $S w-5$ resis- tance-breaking isolates of tomato spotted wilt virus. J. Gen. Virol. 92:210-215.

Martin, D. P., Murrell, B., Golden, M., Khoosal, A. and Muhire, B. 2015. RDP4: detection and analysis of recombination patterns in virus genomes. Virus Evol. 1:vev003.

McGrann, G. R. D., Grimmer, M. K., Mutasa-Göttgens, E. S. and Stevens, M. 2009. Progress towards the understanding and control of sugar beet rhizomania disease. Mol. Plant Pathol. 10:129-141.

Mehrvar, M. 2009. Diversity of soil-borne sugar beet viruses in Iran: a comprehensive study of beet necrotic yellow vein virus, beet black scorch virus and other pomoviruses in Iran. Ph.D. thesis. Université catholique de Louvain, Louvain, Belgium.

Meunier, A., Schmit, J.-F., Stas, A., Kutluk, N. and Bragard, C. 2003. Multiplex reverse transcription-PCR for simultaneous detection of beet necrotic yellow vein virus, beet soilborne virus, and beet virus Q and their vector Polymyxa betae KESKIN on sugar beet. Appl. Environ. Microbiol. 69:2356-2360.

Meunier, A., Schmit, J. F., Stas, A., Marlier, A., Wauters, A., Steyer, S. and Bragard, C. 2000. The status of rhizomania in Belgium. Parasitica 56:85-97.

Moradi, Z., Mehrvar, M., Nazifi, E. and Zakiaghl, M. 2016. The complete genome sequences of two naturally occurring recombinant isolates of sugarcane mosaic virus from Iran. Virus Genes 52:270-280.

Mouhanna, A. M., Nasrallah, A., Langen, G. and Schlösser, E. 2002. Surveys for beet necrotic yellow vein virus (the cause of Rhizomania), other viruses, and soil-borne fungi infecting sugar beet in Syria. J. Phytopathol. 150:657-662.

Prillwitz, H. and Schlösser, E. 1992. Beet soil-borne virus: occurrence, symptoms and effect on plant development. Meded. Fac. Landbouwwet. Rijksuniv. Gent 57:295-302.

Ratti, C., Clover, G. R. G., Autonell, C. R., Harju, V. A. and Henry, C. M. 2005. A multiplex RT-PCR assay capable of distinguishing beet necrotic yellow vein virus types A and B. $J$. Virol. Methods 124:41-47.

Rozas, J., Ferrer-Mata, A., Sánchez-DelBarrio, J. C., Guirao-Rico, S., Librado, P., Ramos-Onsins, S. E. and Sánchez-Gracia, A. 2017. DnaSP 6: DNA sequence polymorphism analysis of large data sets. Mol. Biol. Evol. 34:3299-3302.

Rush, C. M., Liu, H.-Y., Lewellen, R. T. and Acosta-Leal, R. 2006. The continuing saga of rhizomania of sugar beets in the United States. Plant Dis. 90:4-15.

Simon, A. E. and Miller, W. A. 2013. 3' cap-independent translation enhancers of plant viruses. Annu. Rev. Microbiol. 67:2142.

Skuzeski, J. M., Nichols, L. M., Gesteland, R. F. and Atkins, J. F. 1991. The signal for a leaky UAG stop codon in several plant viruses includes the two downstream codons. J. Mol. Biol. 218:365-373.

Sperschneider, J. and Datta, A. 2010. DotKnot: pseudoknot prediction using the probability dot plot under a refined energy model. Nucleic Acids Res. 38:e103. 
Tamada, T. and Kondo, H. 2013. Biological and genetic diversity of plasmodiophorid-transmitted viruses and their vectors. $J$. Gen. Plant Pathol. 79:307-320.

Torrance, L. 2008. Pomovirus. In: Encyclopedia of virology, 3rd ed., eds. by B. W. J. Mahy and M. H. V. Van Regenmortel, pp. 282-287. Academic Press, London, UK.

Torrance, L., Wright, K. M., Crutzen, F., Cowan, G. H., Lukhovitskaya, N. I., Bragard, C. and Savenkov, E. I. 2011. Unusual features of pomoviral RNA movement. Front Microbiol. 2:259.

Verhoyen, M., Van Den Bossche, M. and Van Steyvoort, L. 1987.
New sugarbeet virus identification in Belgium. Rev. Agric. 40:1463-1468 (in French).

Wang, B., Li, M., Han, C., Li, D. and Yu, J. 2008. Complete genome sequences of two Chinese beet soil-borne virus isolates provide evidence that the genome is highly conserved. $J$. Phytopathol. 156:487-488.

Weiland, J. J., Van Winkle, D., Edwards, M. C., Larson, R. L., Shelver, W. L., Freeman, T. P. and Liu, H.-Y. 2007. Characterization of a U.S. isolate of beet black scorch virus. Phytopathology 97:1245-1254. 